\title{
http://bjas.journals.ekb.eg \\ Intravenous Versus Oral Iron Therapy for Postpartum Anemia
}

M.R.Fayed, M.A.Mahmoud, A.S.Ebrahem and A.K.Ibrahim

Professor of Obstetrics and Gynecology Dept., Faculty of Medicine, Benha Univ., Benha, Egypt

E-Mail:ahmed85@gmail.com

\begin{abstract}
Postpartum iron deficiency anemia (IDA) is a common problem throughout the world. Various treatment modalities like oral iron therapy, parenteral iron therapy and blood transfusion are used to treat anemia in the postpartum period. This study aimed to compare efficacy, safety, tolerability and side effects of treatment with either intravenous iron sucrose or oral ferrous gluconate for postpartum iron deficiency anemia to ascertain whether administering intravenous iron sucrose to women with postpartum anemia results in higher hemoglobin concentration and improved iron stores than using standard treatment with oral iron. This comparative, randomized and prospective study conducted in Obstetrics and Gynecology Department of Benha University Hospital and Benha Teaching Hospital in the period from 1/11/2018 to 30/9/2019. This study was carried on 60 women with postpartum iron deficiency anemia. The inclusion criteria was hemoglobin concentration $<10 \mathrm{~g} / \mathrm{dl}$ and serum ferritin of $<15 \mu \mathrm{g} / \mathrm{l}$ at 24 hours post-delivery. The exclusion criteria was intolerance to iron derivatives, peripartum blood transfusion or a history of asthma, thromboembolism, seizure, alcohol, drug abuse, renal or hepatic dysfunction. Patients were randomized into either group 1, where they were received intravenous iron sucrose (Inj Sacrofer 100mg/Amp), two to three doses were given on alternate days as an intravenous infusion in $250 \mathrm{ml}$ of $0.9 \%$ sodium chloride for at least 2 hrs or group 2, where they were received oral ferrous gluconate (Tab Glucofer) 300mg twice daily 2 hrs after meals for 6 weeks. Blood samples for hemoglobin $(\mathrm{Hb})$ level, hematocrit $(\mathrm{Hct})$ value, mean corpuscular volume (MCV), mean corpuscular hemoglobin concentration (MCHC), C- reactive protein (CRP) test, serum ferritin and serum total iron binding capacity (TIBC) were measured on day $0,7,14$ and 40 postpartum. There was no statistically significant difference in Day $0 \mathrm{Hb}$ among group 1 (I.V Iron group) compared to group 2 (Oral Iron group). There was statistically significant increase in Day $7 \mathrm{Hb}$, Day $14 \mathrm{Hb}$ and Day $40 \mathrm{Hb}$ level among group 1 than group 2 . There was no statistically significant difference between group 1 and group 2 regarding Day 0 Hct. There was statistically significant increase in Day 7 Hct and Day 14 and Day 40 Hct among group 1 than group 2. There was no statistically significant difference between group 1 and group 2 regarding Day $0 \mathrm{MCV}$. There was statistically significant increase in Day $7 \mathrm{MCV}$, Day $14 \mathrm{MCV}$ and Day $40 \mathrm{MCV}$ among group 1 than group 2. There was no statistically significant difference between group 1 and group 2 regarding Day 0 MCHC. There was statistically significant increase in Day 7 MCHC, Day $14 \mathrm{MCHC}$ and Day $40 \mathrm{MCHC}$ among group 1 than group 2. There was no statistically significant difference between group 1 and group 2 regarding Day 0 Ferritin. There was statistically significant increase in Day 7 Ferritin, Day 14 Ferritin and Day 40 Ferritin among group 1 than group 2. There was no statistically significant difference between group 1 and group 2 regarding nausea, dyspepsia, facial flushing and constipation. Intravenous iron sucrose is more effective than oral ferrous gluconate regarding the increase of hemoglobin level. Ferritin levels rose rapidly in those treated with intravenous iron and remained significantly higher than in those treated with oral iron without any significant serious side effects .
\end{abstract}

Keywords: Ferritin, Oral ferrous gluconate, Intravenous iron sucrose, Postpartum iron deficiency anemia.

\section{Introduction}

The World Health Organization (WHO) defines anemia in pregnancy as a hemoglobin concentration of $<11 \mathrm{~g} / \mathrm{dl}$ and postpartum anemia as a hemoglobin concentration of $<10.0 \mathrm{~g} / \mathrm{dl}$. The National Institute for Health and Care Excellence (NICE) defines anemia by $\mathrm{Hb}<110 \mathrm{~g} / \mathrm{l}$ in first trimester, $<105 \mathrm{~g} / \mathrm{l}$ in second and third trimesters and $<100 \mathrm{~g} / \mathrm{l}$ in postpartum period [1].

Postpartum anemia is a common problem throughout the world. In developing countries, the prevalence of postpartum anemia is considerably higher where it is a major cause of maternal morbidity and mortality [2]. Nearly a third of women are anaemic postpartum. Worldwide prevalence of anemia in pregnancy is estimated to be around $38 \%$ (compared to $29 \%$ of non-pregnant women) ${ }^{[3]}$.

Postpartum hemoglobin $(\mathrm{Hb})$ levels of $<10 \mathrm{~g} / \mathrm{dl}$ are observed in up to $30 \%$ of women, with more severe anemia $(\mathrm{Hb}<8 \mathrm{~g} / \mathrm{dl})$ seen in $10 \%$ [4].
The major causes of postpartum anemia are prepartum iron deficiency anemia in combination with excessive blood losses at delivery [5].

Iron deficiency is the principal cause. This is partly attributable to an iron deficit during pregnancy, caused by the increased iron demands of the fetoplacental unit and an increased maternal red cell mass. Irrespective of mode of delivery, blood loss is a contributing factor, with $5 \%$ of deliveries involving loss of more than 1L [6].

Various treatment modalities like oral iron therapy, intramuscular iron therapy, intravascular iron therapy and blood transfusion are used to treat anemia in the postpartum period [7].

The standard approach to treatment in the majority of UK institutions is oral iron therapy, with blood transfusion reserved for more severe or symptomatic cases ${ }^{[8]}$ However, the transfusion trigger is clinician dependent and a number of studies and audits have shown that the transfusion level varies widely 
between medical teams and institutions, with a significant proportion of transfusions given inappropriately [9].

Among the various iron salts, ferrous gluconate most commonly is used [10]. Oral iron is unreliable in the treatment of severe anemia since the endogenous iron stores are usually depleted and less iron is provided for sufficient erythropoiesis. The reason for this includes limited absorption and gastrointestinal adverse effects that affect compliance and low plasma transferring saturation level, which lead to functional iron deficiency [11].

Intramuscular iron therapy has been shown to reduce the proportion of women with anemia. However injections tend to be painful and there is significant risk of permanent skin staining. Its use is therefore generally discouraged [12].

This study aimed to compare the efficacy, safety, tolerability and side effects of treatment with either intravenous iron sucrose or oral ferrous gluconate for postpartum iron deficiency anemia to ascertain whether administering intravenous iron sucrose to women with postpartum anemia results in higher hemoglobin concentration and improved iron stores than using standard treatment with oral iron.

\section{Patients and methods}

Type of study: Randomized controlled study. Study settings: Benha University Hospital and Benha Teaching Hospital.

Ethical considerations: This study was approved by the Ethics Committee of the Faculty of Medicine, Benha University in the period from 1/11/2018 to $30 / 9 / 2019$. Informed consent was obtained from each participant before study start after explaining the aims, methods, reasonably anticipated benefits, and potential hazards of the study.

Sample size justification: 60 participants with postpartum iron deficiency anemia fulfilling the inclusion/exclusion criteria. (Postpartum iron deficiency anamia was defined if hemoglobin of $<10$ $\mathrm{g} / \mathrm{dl}$, serum ferritin < 15 microgram/l and microcytic hypochromic to normocytic hypochromic picture on peripheral smear at 24 hours post-delivery).

\section{The inclusion criteria:}

1 -Women aged 18 years or more.

2-All patients with postpartum anemia as hemoglobin 7-9.9 g/dl and serum Ferritin <15 microgram/l at $24-48$ hours post-delivery.

\section{The exclusion criteria:}

1 -Women with severe anemia $(\mathrm{Hb}<7 \mathrm{~g} / \mathrm{dl})$ as they need blood transfusion.

2-Allergic history or intolerance to iron derivatives.

3-Peripartum blood transfusion.

4-Patients with chronic disease i.e. chronic renal failure, chronic hypertension and chronic liver disease.

5-History of asthma, thromboembolism, seizures, alcohol or drug abuse, and those having signs of infection.

\subsection{Methodology}

1- A detailed history.

2-Examination (General, physical, systemic and local examination to assess anemia).

3-Patients were assigned to 2 groups of 30 each using computer generated random number sequence.

4-Treatment were started at 24-48 hours after delivery. Patients were randomized either group 1 , where they were received intravenous iron sucrose or group 2, where they were received oral ferrous gluconate.

\section{Group 1}

Intravenous iron sucrose $100 \mathrm{mg} / 5 \mathrm{ml}$ solution (Sacrofer; Amoun Co-Egypt) was given in divided three doses on alternate days for three days. Iron sucrose was administrated as an intravenous drip infusion in $250 \mathrm{ml}$ sterile $0.9 \%$ sodium chloride solution in at least 2 hours. It was administered in hospital where facilities for monitoring and resuscitation are available. Dose was calculated by the following Ganzoni formula: Weight (in $\mathrm{kgs}) \times($ Target hemoglobin-Actual hemoglobin) $\times 2.4$ [13] .

Target hemoglobin was set at $12 \mathrm{~g} / \mathrm{dl}$, actual hemoglobin in gram per deciliter is the patient's hemoglobin level on inclusion; 2.4 is a correction factor. Total required dose of iron was divided in three doses, and given on alternate days for three days. This group wasn't received any further iron therapy. They were asked to note any symptoms or adverse effects of treatment.

\section{Group 2}

Ferrous gluconate 300mg (Glucofer; Cid Egypt) was given twice daily 2 hours after meals for 6 weeks. They was given a date on which to stop oral iron therapy. Women was advised to document treatment compliance and symptoms on a diary chart that provided for that purpose.

5-Blood samples of patients was taken at the day of recruitment into the study (day 0) and the rest of the samples were taken in day 7 , day 14 , day 40 after the start of the treatment. These time-points were chosen to minimize any inconvenience to the patients. The time- points are also chosen to detect any differences in the speed of restoration of hemoglobin and iron stores. Hemoglobin, haematocrit, red cell indices, mean corpuscular volume and mean corpuscular hemoglobin levels were measured. Iron status markers were measured including serum ferritin and total iron binding capacity. The C-reactive protein level will be also measured at each time-point to exclude artificial elevation of serum ferritin levels due to an acute inflammatory response.

6-The incidence and severity of adverse events were recorded. The intravenous iron sucrose were administered in Hospital where there are facilities for monitoring and resuscitation. Vital signs (pulse, 
blood pressure and oxygen saturation) were monitored during and for 30 minutes after infusion.

\subsection{Statistical analysis}

The data were coded, entered and processed on computer using SPSS (version 23). The results were represented in tabular and diagrammatic forms then interpreted.

Mean, standard deviation, range, frequency, and percentage were use as descriptive statistics.

The following test was done:

- Chi-Square test $\mathbf{X}^{2}$ was used to test the association variables for categorical data.

- Student's t-test was used to assess the statistical significance of the difference between two population means in a study involving independent samples.

$P$ value was considered significant as the following:

$* \mathrm{P}>0.05:$ Non significant

$* \mathrm{P} \leq 0.05$ : Significant

\section{Results}

There was no statistically significant difference between group 1 (I.V Iron group) and group 2 (Oral Iron group) regarding age, parity, multiple Pregnancy, bleeding during pregnancy Table (1).

There was no statistically significant difference in Day $0 \mathrm{Hb}$ among group 1 (I.V Iron group) compared to group 2 (Oral Iron group). There was statistically significant increase in Day $7 \mathrm{Hb}$, Day $14 \mathrm{Hb}$ and Day
$40 \mathrm{Hb}$ among group 1 (I.V Iron group) than group 2 (Oral Iron group) Table (2).

There was no statistically significant difference between group 1 (I.V Iron group) and group 2 (Oral Iron group) regarding Day 0 Hct. There was statistically significant increase in Day 7 Hct and Day 14 and Day $40 \mathrm{Hct}$ among group 1 (I.V Iron group) than group 2 (Oral Iron group) Table (3).

There was no statistically significant difference between group 1 (I.V Iron group) and group 2 (Oral Iron group) regarding Day $0 \mathrm{MCV}$. There was statistically significant increase in Day $7 \mathrm{MCV}$, Day $14 \mathrm{MCV}$ and Day $40 \mathrm{MCV}$ among group 1 (I.V group) than group 2 (Oral Iron group) Table (4).

There was no statistically significant difference between group 1 (I.V group) and group 2 (Oral Iron group) regarding Day 0 MCHC. There was statistically significant increase in Day $7 \mathrm{MCHC}$, Day $14 \mathrm{MCHC}$ and Day $40 \mathrm{MCHC}$ among group 1 (I.V Iron group) than group 2 (Oral Iron group) Table (5).

There was no statistically significant difference between group 1 (I.V group) and group 2 (Oral Iron group) regarding D0 Ferritin. There was statistically significant increase in Day 0 Ferritin, Day 7 Ferritin, Day 14 Ferritin and Day 40 Ferritin among group 1 (I.V Iron group) than group 2 (Oral Iron group) Table (6).

There was no statistically significant difference between group 1 (I.V Iron group) and group 2 (Oral Iron group) regarding Nausea, dyspepsia, Facial Flushing and Constipation Table (7).

Table (1) Comparison between group 1 (I.V Iron group) and group 2 (Oral Iron group) regarding Age, parity, Multiple Pregnancy, Bleeding during Pregnancy.

\begin{tabular}{|c|c|c|c|c|c|c|}
\hline \multirow[b]{2}{*}{ Age } & & & $\begin{array}{c}\text { Group 1 } \\
\text { (I.V Iron group) } \\
(\text { No.= 30) }\end{array}$ & $\begin{array}{c}\text { Group 2 } \\
\text { (Oral Iron group) } \\
\text { (No.= 30) }\end{array}$ & t.test & P. value \\
\hline & \multicolumn{2}{|c|}{ Mean \pm SD } & $27.60 \pm 6.185$ & $26.07 \pm 5.656$ & 1.002 & 0.320 \\
\hline \multirow{12}{*}{ Parity } & P1 & No. & 5 & 10 & \multirow{11}{*}{5.497} & \multirow{11}{*}{0.358} \\
\hline & & $\begin{array}{l}\% \\
\text { No. }\end{array}$ & $\begin{array}{c}16.7 \% \\
9\end{array}$ & $\begin{array}{c}33.3 \% \\
10\end{array}$ & & \\
\hline & $\mathrm{P} 2$ & $\%$ & $30.0 \%$ & $33.3 \%$ & & \\
\hline & & No. & 10 & 5 & & \\
\hline & 53 & $\%$ & $33.3 \%$ & $16.7 \%$ & & \\
\hline & \multirow{2}{*}{ P4 } & No. & 5 & 4 & & \\
\hline & & $\%$ & $16.7 \%$ & $13.3 \%$ & & \\
\hline & \multirow{2}{*}{ P5 } & No. & 0 & 1 & & \\
\hline & & $\%$ & $.0 \%$ & $3.3 \%$ & & \\
\hline & \multirow{2}{*}{ P6 } & No. & 1 & 0 & & \\
\hline & & $\%$ & $3.3 \%$ & $.0 \%$ & & \\
\hline & & $\begin{array}{l}\text { No. } \\
0\end{array}$ & 30 & 30 & \multirow{3}{*}{0} & \multirow{3}{*}{1} \\
\hline Multiple & 110 & $\%$ & $100.0 \%$ & $\begin{array}{c}100.0 \% \\
0 .\end{array}$ & & \\
\hline Pregnancy & yes & $\begin{array}{l}\text { No. } \\
\%\end{array}$ & $\begin{array}{c}0 \\
.0 \%\end{array}$ & $\begin{array}{c}0 \\
.0 \%\end{array}$ & & \\
\hline Bleeding & no & No. & 30 & 30 & \multirow{4}{*}{0} & \multirow{4}{*}{1} \\
\hline during & & $\%$ & $100.0 \%$ & $100.0 \%$ & & \\
\hline Pregnancy & yes & No. & 0 & 0 & & \\
\hline & & $\%$ & $.0 \%$ & $.0 \%$ & & \\
\hline
\end{tabular}


Table (2) Comparison between group 1 (I.V Iron group) and group 2 (Oral Iron group) regarding hemoglobin (Hb).

\begin{tabular}{|c|c|c|c|c|c|}
\hline \multicolumn{2}{|c|}{$\begin{array}{c}\mathrm{Hb} \\
\text { Reference Range: } \\
\text { 12-15.5 g/dl }\end{array}$} & $\begin{array}{c}\text { Group 1 } \\
\text { (I.V Iron group) } \\
(\text { No.= } \mathbf{3 0})\end{array}$ & $\begin{array}{c}\text { Group } 2 \\
\text { (Oral Iron group) } \\
(\text { No.= 30) }\end{array}$ & t.test & P. value \\
\hline Day 0 & Rang & $7.8-8.7$ & $8.1-9.5$ & $-2.15-$ & 0.06 \\
\hline $\mathrm{Hb}$ & Mean \pm SD & $8.37 \pm 0.23$ & $8.52 \pm 0.29$ & & \\
\hline Day 7 & Rang & $8.5-11.0$ & $8.2-9.8$ & 12.86 & .000 \\
\hline Hb & Mean \pm SD & $9.13 \pm 0.42$ & $8.82 \pm 0.36$ & & \\
\hline Day 14 & Rang & $10.6-11.8$ & $8.6-10.2$ & 25.40 & .000 \\
\hline $\mathrm{Hb}$ & Mean \pm SD & $11.28 \pm 0.33$ & $9.157 \pm 0.32$ & & \\
\hline Day 40 & Rang & $11.7-13.0$ & $9.9-12.4$ & 9.07 & .000 \\
\hline $\mathrm{Hb}$ & Mean \pm SD & $12.37 \pm 0.31$ & $11.16 \pm 0.66$ & & \\
\hline
\end{tabular}

Table (3) Comparison between group 1 (I.V Iron group) and group 2 (Oral Iron group) regarding hematocrit value (Hct).

\begin{tabular}{|c|c|c|c|c|c|}
\hline \multicolumn{2}{|c|}{$\begin{array}{c}\text { Hct } \\
\text { Reference Range: } \\
\text { 35-45\% } \\
\end{array}$} & $\begin{array}{c}\text { Group } 1 \\
\text { (I.V Iron group) } \\
(\text { No.= 30) }\end{array}$ & $\begin{array}{c}\text { Group } 2 \\
\text { (Oral Iron group) } \\
(\text { No.= 30) } \\
\end{array}$ & t.test & P. value \\
\hline Day 0 & Rang & $21.66-26.52$ & $22.02-31.35$ & & \\
\hline Hct & Mean \pm SD & $24.78 \pm 1.54$ & $25.56 \pm 1.89$ & $-1.734-$ & 0.088 \\
\hline Day 7 & Rang & $30.25-35.60$ & $24.53-33.54$ & & \\
\hline Hct & Mean \pm SD & $33.06 \pm 1.55$ & $27.68 \pm 1.84$ & 12.251 & .000 \\
\hline Day 14 & Rang & $31.96-36.96$ & $30.95-36.52$ & & \\
\hline Hct & Mean \pm SD & $34.58 \pm 1.49$ & $33.52 \pm 1.49$ & 2.76 & 0.008 \\
\hline Day 40 & Rang & $33.70-44.40$ & $32.64-42.52$ & & \\
\hline Hct & Mean \pm SD & $37.53 \pm 2.94$ & $34.66 \pm 1.92$ & $1.31-$ & 0.001 \\
\hline
\end{tabular}

Table (4) Comparison between group 1 (I.V Iron group) and group 2 (Oral Iron group) regarding mean corpuscular volume $(\mathrm{MCV})$.

\begin{tabular}{|c|c|c|c|c|c|}
\hline \multicolumn{2}{|c|}{$\begin{array}{c}\text { MCV } \\
\text { Reference Range } \\
\mathbf{8 0 - 1 0 0 ~ f l / c e l l ~}\end{array}$} & \multirow{2}{*}{$\begin{array}{c}\begin{array}{c}\text { Group 1 } \\
\text { (I.V Iron group) } \\
\text { (No.= 30) }\end{array} \\
61.12-73.12\end{array}$} & \multirow{2}{*}{$\begin{array}{c}\begin{array}{c}\text { Group 2 } \\
\text { (Oral Iron group) } \\
(\text { No.= 30) }\end{array} \\
56.78-78.18\end{array}$} & \multirow{2}{*}{$\begin{array}{l}\text { t.test } \\
1.044\end{array}$} & \multirow{2}{*}{$\begin{array}{r}\text { P. value } \\
0.301\end{array}$} \\
\hline Day 0 & Rang & & & & \\
\hline MCV & Mean \pm SD & $66.86 \pm 3.18$ & $65.67 \pm 5.40$ & & \\
\hline Day 7 & Rang & $73.60-80.42$ & $63.28-82.15$ & 6.579 & .000 \\
\hline MCV & Mean \pm SD & $77.22 \pm 2.11$ & $71.44 \pm 4.35$ & & \\
\hline Day 14 & Rang & $81.51-88.49$ & $67.36-88.52$ & 9.481 & .000 \\
\hline MCV & Mean \pm SD & $85.34 \pm 2.28$ & $75.99 \pm 4.89$ & & \\
\hline Day 40 & Rang & $80.05-95.74$ & $77.82-99.92$ & 0.528 & .000 \\
\hline MCV & Mean \pm SD & $87.87 \pm 4.54$ & $79.176 \pm 5.63$ & & \\
\hline
\end{tabular}

Table (5) Comparison between group 1 (I.V group) and group 2 (Oral Iron group) regarding mean corpuscular hemoglobin concentration (MCHC).

\begin{tabular}{lccccc}
\hline \multicolumn{1}{c}{$\begin{array}{c}\text { MCHC } \\
\text { Reference Range } \\
\text { 32-37 g/dl }\end{array}$} & $\begin{array}{c}\text { Group 1 } \\
\text { (I.V Iron group) } \\
(\text { No.= 30) }\end{array}$ & $\begin{array}{c}\text { Group 2 } \\
\text { (Oral Iron group) } \\
\text { (No.= 30) }\end{array}$ & t.test & P. value \\
\hline Day 0 & Rang & $19.5-30.4$ & $19.1-30.3$ & 1.917 & 0.06 \\
MCHC & Mean \pm SD & $25.07 \pm 3.11$ & $23.64 \pm 2.68$ & & \\
Day 7 & Rang & $26.3-35.4$ & $19.8-32.5$ & 6.957 & .000 \\
MCHC & Mean \pm SD & $29.94 \pm 2.506$ & $25.14 \pm 2.82$ & & .000 \\
Day 14 & Rang & $23.4-33.3$ & $22.8-34.3$ & 6.670 & \\
MCHC & Mean + SD & $31.35 \pm 1.87$ & $27.167 \pm 2.88$ & & 0.04 \\
Day 40 & Rang & $32.9-37.1$ & $28.9-36.2$ & 5.914 & \\
MCHC & Mean \pm SD & $35.27 \pm 1.17$ & $31.52 \pm 2.26$ & & \\
\hline
\end{tabular}


Table (6) Comparison between group 1 (I.V Iron group) and group 2 (Oral Iron group) regarding serum Ferritin.

\begin{tabular}{|c|c|c|c|c|c|}
\hline \multicolumn{2}{|c|}{$\begin{array}{l}\text { Serum Ferritin } \\
\text { Reference Range } \\
\text { 6-159 ng/mL }\end{array}$} & $\begin{array}{c}\text { Group 1 } \\
\text { (I.V Iron group) } \\
(\text { No.= 30) }\end{array}$ & $\begin{array}{c}\text { Group } 2 \\
\text { (Oral Iron group) } \\
(\text { No.= 30) }\end{array}$ & t.test & P. value \\
\hline Day 0 & Rang & $10.4-12.2$ & $9.5-14.8$ & -2.234 & 0.09 \\
\hline Ferritin & Mean \pm SD & $11.45 \pm 0.50$ & $12.01 \pm 1.36$ & & \\
\hline Day 7 & Rang & $44.7-52.2$ & $12.2-19.3$ & 60.934 & .000 \\
\hline Ferritin & Mean \pm SD & $48.03 \pm 2.23$ & $15.23 \pm 1.93$ & & \\
\hline Day 14 & Rang & $33.4-50.2$ & $16.3-24.3$ & 29.975 & .000 \\
\hline Ferritin & Mean $\pm \mathrm{SD}$ & $41.49 \pm 3.14$ & $20.18 \pm 2.30$ & & \\
\hline Day 40 & Rang & $41.2-49.1$ & $14.8-21.3$ & 47.976 & .000 \\
\hline Ferritin & Mean \pm SD & $44.53 \pm 2.24$ & $17.69 \pm 2.09$ & & \\
\hline
\end{tabular}

Table (7) Comparison between group 1 (I.V Iron group) and group 2 (Oral Iron group) regarding side effects of treatments.

\begin{tabular}{|c|c|c|c|c|c|c|}
\hline \multicolumn{3}{|c|}{ Side effects } & $\begin{array}{c}\text { Group 1 } \\
\text { (I.V Iron group) } \\
(\text { No.= 30) }\end{array}$ & $\begin{array}{c}\text { Group 2 } \\
\text { (Oral Iron group) } \\
(\text { No.= 30) }\end{array}$ & t.test & P. value \\
\hline \multirow{4}{*}{ Nausea } & no & No. & 29 & 28 & \multirow{4}{*}{3.018} & \multirow{4}{*}{0.221} \\
\hline & & $\%$ & $96.7 \%$ & $93.3 \%$ & & \\
\hline & yes & No. & 1 & 2 & & \\
\hline & & $\%$ & $3.3 \%$ & $6.6 \%$ & & \\
\hline \multirow{4}{*}{ Dyspepsia } & no & No. & 29 & 27 & \multirow{4}{*}{1.405} & \multirow{4}{*}{0.495} \\
\hline & & $\%$ & $96.7 \%$ & $90.0 \%$ & & \\
\hline & yes & No. & 1 & 3 & & \\
\hline & & $\%$ & $3.3 \%$ & $10 \%$ & & \\
\hline \multirow{4}{*}{ Facial Flushing } & no & No. & 28 & 28 & \multirow{4}{*}{0} & \multirow{4}{*}{1} \\
\hline & & $\%$ & $93.3 \%$ & $93.3 \%$ & & \\
\hline & yes & No. & 2 & 2 & & \\
\hline & & $\%$ & $6.7 \%$ & $6.7 \%$ & & \\
\hline \multirow{4}{*}{ Constipation } & no & No. & 30 & 25 & \multirow{4}{*}{5.455} & \multirow{4}{*}{0.065} \\
\hline & & $\%$ & $100.0 \%$ & $83.3 \%$ & & \\
\hline & yes & No. & 0 & 5 & & \\
\hline & & $\%$ & $.0 \%$ & $16.7 \%$ & & \\
\hline
\end{tabular}

\section{Discussion}

This study showed that, there was no statistically significant difference between group 1 (I.V Iron group) and group 2 (Oral Iron group) regarding age, parity, multiple pregnancy, bleeding during pregnancy, history of $\mathrm{PPH}$ and history of chronic diseases such as DM or HTN.

The current study showed that intravenous iron significantly increases the mean level of $\mathrm{Hb}$ from 8.37 $\mathrm{g} / \mathrm{dl}$ at day 0 to $9.13 \mathrm{~g} / \mathrm{dl}$ at day 5 while oral iron increase the mean $\mathrm{Hb}$ level from $8.52 \mathrm{~g} / \mathrm{dl}$ to $8.82 \mathrm{~g} / \mathrm{dl}$, the mean change of $\mathrm{Hb}$ level from the baseline at day 5 significantly higher with the first group (IV iron) $0.70 \mathrm{~g} / \mathrm{dl}$ than the second group (oral iron) $0.30 \mathrm{~g} / \mathrm{dl}$.

This agrees with [14] who found that, intravenous ferrous sucrose significantly increases the mean level of $\mathrm{Hb}$ from $8.48 \mathrm{~g} / \mathrm{dl}$ at day 0 to $9.9 \mathrm{~g} / \mathrm{dl}$ at day 5 while oral ferrous sulphate increase the mean $\mathrm{Hb}$ level from $8.52 \mathrm{~g} / \mathrm{dl}$ to $8.82 \mathrm{~g} / \mathrm{dl}$, the mean change of $\mathrm{Hb}$ level from the baseline at day 5 significantly higher with the first group (IV iron) $1.45 \mathrm{~g} / \mathrm{dl}$ than the second group (oral iron) $0.3 \mathrm{~g} / \mathrm{dl}$.
This study showed that, intravenous iron increases the mean level of $\mathrm{Hb}$ from $8.37 \mathrm{~g} / \mathrm{dl}$ to $11.28 \mathrm{~g} / \mathrm{dl}$ at day 14 while oral iron increase the mean $\mathrm{Hb}$ level from $8.52 \mathrm{~g} / \mathrm{dl}$ to $9.15 \mathrm{~g} / \mathrm{dl}$, the mean change of $\mathrm{Hb}$ level from the baseline at day 14 significantly higher with the first group (IV iron) $2.91 \mathrm{~g} / \mathrm{dl}$ than the second group (Oral iron) $0.63 \mathrm{~g} / \mathrm{dl}$.

The mean increase in $\mathrm{Hb}$ level at day 14 in our study is supported by the study conducted by [15] in which the mean increase in $\mathrm{Hb}$ by day 14 was higher in the i.v. group $(3.1 \mathrm{~g} / \mathrm{dl})$ than in the oral group $(1.9 \mathrm{~g} / \mathrm{dl})$.

Similarly, [16] studied 40 patients with postpartum IDA who were divided into two groups. The i.v. group was treated with i.v. iron sucrose (300-600 mg) and the oral group was treated by ferrous fumarate $300 \mathrm{mg}$ once daily for 14 days; on day 14 , the increase in mean $\mathrm{Hb}$ in the i.v. group was higher $(2.4 \mathrm{~g} / \mathrm{dl})$ than that in the oral group $(1.2 \mathrm{~g} / \mathrm{dl})$, suggesting that i.v. iron sucrose increased the $\mathrm{Hb}$ level more rapidly than oral ferrous fumarate in postpartum anemia without any serious side effects. 
This study showed that, at day 40 , we observed that $\mathrm{Hb}$ level increased from $8.37 \mathrm{~g} / \mathrm{dl}$ to $12.37 \mathrm{~g} / \mathrm{dl}$ with intravenous iron and increased from $8.52 \mathrm{~g} / \mathrm{dl}$ to $11.6 \mathrm{~g} / \mathrm{dl}$ with oral iron.

[17] who studied patients with postpartum irondeficiency anemia, divided into two groups (i.v. iron and oral iron), and reported that i.v. ferrous sucrose increased $\mathrm{Hb}$ level from 7.2 to $11.49 \mathrm{~g} / \mathrm{dl}$ at day 40 , whereas oral ferrous sulfate increased levels from 7.1 to $11.17 \mathrm{~g} / \mathrm{dl}$, thus proving that i.v. iron was more effective than oral iron.

The results of our study at day 40 were supported by the study conducted by [18], who reported that no significant difference in the improvement of hemoglobin levels after 4 weeks as it increased from $7.9 \mathrm{~g} / \mathrm{dl}$ to $12 \mathrm{~g} / \mathrm{dl}$ with intravenous iron and from $7.7 \mathrm{~g} / \mathrm{dl}$ to 11.9 with oral iron.

This agrees also with [19] who studied 44 women with postpartum IDA anemia, were randomized into two groups, IV group received intravenous iron sucrose $200 \mathrm{mg}$ on day 2 and 4 following recruitment and oral group received oral ferrous sulphate $200 \mathrm{mg}$ twice daily for 6 weeks. They reported that there was no significant difference in mean increase of $\mathrm{Hb}$ level at day 40 between both groups as $\mathrm{Hb}$ level increased from $7.3 \mathrm{~g} / \mathrm{dl}$ to $11.5 \mathrm{~g} / \mathrm{dl}$ with intravenous iron and from $7.5 \mathrm{~g} / \mathrm{dl}$ to 11.2 with oral iron, they explained these results by high compliance of oral iron,.

reported that there was no significant difference in mean $\mathrm{Hb}$ level between intravenous iron plus oral iron and the placebo plus oral iron after 6 weeks as it increased from $7.3 \mathrm{~g} / \mathrm{dl}$ to $12.2 \mathrm{~g} / \mathrm{dl}$ with intravenous iron and from $7.2 \mathrm{~g} / \mathrm{dl}$ to $12.2 \mathrm{~g} / \mathrm{dl}$ with the placebo [20],.

Blood indices (HCT, MCV and MCHC) were significantly higher with intravenous iron than oral iron at day 5, day 14 and at day 40.

According to [21] who studied 150 women with postpartum anemia $(\mathrm{Hb}<8 \mathrm{~g} / \mathrm{dl})$ randomized into a first group treated by i.v. ferrous sucrose $600 \mathrm{mg}$ and a second group treated by oral ferrous sulfate $200 \mathrm{mg}$ twice daily for 4 weeks, the results of this study reported that $\mathrm{HCT}, \mathrm{MCV}$, and $\mathrm{MCHC}$ were higher with i.v. iron sucrose than with oral ferrous sulfate after 6 weeks; hence, our study matched with these results.

These results were supported by previous studies as, [22], they observed that HCT, MCV and MCHC were significantly higher with intravenous iron than oral iron at day 5, day 14 and at day 40 .

The mean increase in serum ferritin level was significantly higher with intravenous iron (44.53 $\mu \mathrm{g} / \mathrm{L})$ than with oral iron $(17.69 \mu \mathrm{g} / \mathrm{L})$ at day 40 due to delivery of large amount of ferrous directly in the haemopoietic system. The mean increase in serum ferritin at day 40 in our study matched with the previous studies as [19] who observed that the mean increase in serum ferrtin was $28.8 \mu \mathrm{g} / \mathrm{L}$ with intravenous iron and $4 \mu \mathrm{g} / \mathrm{L}$ with oral iron at day 40 , also [22] reported that the mean increase in serum ferritin was $31 \mu \mathrm{g} / \mathrm{L}$ with intravenous iron and was $3.9 \mu \mathrm{g} / \mathrm{L}$ with oral iron at day 40 .

In our study, no statistically significant difference between group 1 (I.V Iron group) and group 2 (Oral Iron group) regarding adverse effects (Nausea, Dyspepsia, Facial Flushing and Constipation).

This finding was supported by previous larger studies that had investigated the safety profile of intravenous iron in postpartum period [23].

In the present study, we observed that in the first group (IV iron), no serious side effects were reported, two women complained of facial flushing during the infusion of intravenous iron describing it as a warm tingling sensation, this was transient and resolved immediately after the infusion was completed.

studied 400 postpartum anemic patients who received a total of 2000 ampoules of iron sucrose, minor general adverse effects including a metallic taste, flushing of the face and burning at the site of intravenous injection occurred in $0.5 \%$ with doses up to $200 \mathrm{mg}$, this finding agree with our study [24],

In our study, in the second group (oral iron), $16.7 \%$ complained of constipation, $6.6 \%$ of women complained of nausea, $10 \%$ complained of dyspepsia and $6.7 \%$ of women complained of Facial Flushing. This finding matched with the previous studies as [19],[22].

\section{Conclusion}

I.V iron sucrose increases the $\mathrm{Hb}$ level more rapidly than oral ferrous gluconate in women with postpartum iron deficiency anemia; it also appears to replenish iron stores more rapidly without any significant serious side effects.

\section{References}

[1] S.Pavord, B.Myers, S.Robinson, S.Allard, J.Strong, C.Oppenheimer. UK guidelines on the management of iron deficiency in pregnancy, London: British Committee for Standards in Haematology, British Journal of Haematology, Vol. 158, PP.559-559, 2012.

[2] N.Milman. Anemia - still a major health problem in many parts of the world! Ann Hematol, vol. 90, pp.369-377, 2011.

[3] G.A.Stevens, M.M.Finucane, L.M.De-Regil, C.J.Paciorek. Global, regional, and national trends in haemoglobin concentration and prevalence of total and severe anaemia in children and pregnant and non-pregnant women for 1995-2011: a systematic analysis of population-representative data, The Lancet Global Health, Vol. 1, (1), pp. 16 $-25,2013$.

[4] R.L.Bergmann, R.Richter, K.E.Bergmann, J.W.Dudenhausen. Prevalence and risk factors for early postpartum anemia, European Journal of Obstetrics and Gynecology and Reproductive Biology, Vol. 150(2), pp. 126-131, 2010. 
[5] J.Allary, J.F.Soubirou, J.Michel, I.Amiel. An individual scoring system for the prediction of postpartum anaemia, Annales Françaisesd' Anesthésie et de Réanimation, vol.32 (1), pp. 1-7, 2013.

[6] P.V Rajan \& Wing D.A. (2010): Postpartum Hemorrhage: Evidence- based Medical Interventions for Prevention and Treatment, Clinical Obstetrics and Gynecology, Volume 53, Issue 1, March 2010, Pages 165-181.

[7] V. Markova, A. Norgaard, K.J. Jørgensen, J.Langhoff-Roos. Treatment for women with postpartum iron deficiency anaemia, Cochrane Database of Systematic Reviews, Vol. 13, (8), Article Number: CD010861, 2015.

[8] j. Studd. Current Progress in Obstetrics and Gynecology, Vol.4, pp.21-56, 2017.

[9] C. Holm, L.L. Thomsen, A. Norgaard, J. Langhoff-Roos. Single- dose intravenous iron infusion versus red blood cell transfusion for treatment of severe postpartum anaemia: a randomized control pilot study, Vox sanguinis The International Journal of Transfusion Medicine, Vol. 112, (2), pp. 122-131, 2017.

[10] P.Santiago. Ferrous versus Ferric Oral Iron Formulations for the Treatment of Iron Deficiency: A Clinical Overview, The Scientific World Journal, Vol. 2012, Article ID 846824, pp.5-12, 2012.

[11] M.Auerbach, L.T.Goodnough, A. Shander. Iron: The new advances in therapy, Best Practice and Research Clinical Anaesthesiology, Vol. 27, (1), pp.131-140, 2013.

[12] Singh.Subhadra, Singh.Saroj, and Kumar.Singh.Punit. A Study to Compare the Efficacy and Safety of Intravenous Iron Sucrose and Intramuscular Iron Sorbitol Therapy for Anemia During Pregnancy, The Journal of Obstetrics and Gynecology of India, Vol. 63, (1), pp. 18-21,2013.

[13] N.Agrawal, $P$ Sharma.Intravenous versus oral iron therapy in treatment of postpartum anaemia. Int J Reprod Contracept Obstet Gynecol; vol.6, pp.3454-7, 2017.

[14] M.E.Helmy, A.E.Al Halaby, N.I.El Khouly, M.M. Youssef.A comparative study of intravenous iron versus oral iron supplementation for postpartum anemia. Menoufia Med J; vol.31, pp.23-30, 2018,

[15] D.E. Broche, C. Guy, S. Amand-Branger, L. Grangeasse, J.J. Terzibachian. Acute postpartum anemia. Clinical practice and interest of intravenous iron. Gynecol Obstet fertile; vol.32pp. 613-619, 2004,

[16] G. Jain, Palaria, S.K. Jha. Intravenous iron in postpartum anemia. J Obstet Gynecol India; vol.63, pp.45-48, 2013,

[17] A Kanwal, W Shadab, A. Rehman . To evaluate safety and efficacy of intravenous iron versus oral iron for postpartum anemia. JSOGP; vol.3, pp.223-226, 2013.

[18] S. Westad, B. Backe, K.A. Salvesen, J. Nakling, I. Økland, I. Borthen. A 12-week randomised study comparing intravenous iron sucrose versus oral ferrous sulphate for treatment of postpartum anemia. Acta Obstet Gynecol Scand, vol.87, pp.916-923, 2008.

[19] N. Bhandal, R. Russell. Intravenous versus oral therapy for postpartum anaemia. BJOG, vol.113, pp.1248-1252, 2006.

[20] M.F. Perello, J.L. Coloma, N. Masoller, M. Palacio. Intravenous ferrous sucrose versus placeboin addition to oral iron therapy for treatment of severe postpartum anemia, a randomized controlled trial. BJOG; vol.121, pp.706-707, 2014.

[21] S. Verna, S.A. Inamdar, N. Malhotra. Intravenous iron therapy versus oral iron in postpartum patients in rural area. JSAFOG; vol.3, pp.67-70, 2011.

[22] Asia K, Wajiha S and Afshan R (2013): To evaluate safety and efficacy of intravenous iron versus oral iron for postpartum anemia, J Obstet Gynaecol Pakistan; vol. 3 (4), pp.223-6, 2013.

[23] C. Breymann, F. Gliga, N. Strizhova, C. Bejenariu. Comparative efficacy and safety of intravenous ferric carboxymaltose in treatment of postpartum anemia. Int J Gynecol Obstet; vol.101, pp.67-73, 2008,

[24] G. Perewunsnyk, A. Huch C. Breymann. Parenteral iron therapy in obsteries: 8 years' experience with iron-sucrose complex. Br J Nutr; vol.88, pp.3-10, 2002. 